\title{
Becoming an Architect in Renaissance Italy: Art, Science and the Career of Baldassarre Peruzzi. Ann C. Huppert. New Haven: Yale University Press, 2015. ix + 222 pp. \$85. [Review]
}

\section{Citation}

Connors, Joseph. 2017. Review of Becoming an Architect in Renaissance Italy: Art, Science, and the Career of Baldassarre Peruzzi by Ann C. Huppert. Renaissance Quarterly 70, no. 1 (Spring): 265-266.

\section{Permanent link}

http://nrs.harvard.edu/urn-3:HUL.InstRepos:41140166

\section{Terms of Use}

This article was downloaded from Harvard University's DASH repository, and is made available under the terms and conditions applicable to Open Access Policy Articles, as set forth at http:// nrs.harvard.edu/urn-3:HUL.InstRepos:dash.current.terms-of-use\#OAP

\section{Share Your Story}

The Harvard community has made this article openly available.

Please share how this access benefits you. Submit a story.

\section{Accessibility}


Becoming an Architect in Renaissance Italy: Art, Science, and the Career of Baldassarre Peruzzi. Ann C. Huppert. New Haven and London: Yale University Press, 2015. ix + 221 pp. $\$ 85$.

Baldassarre Peruzzi (1481-1536) was formed as in Siena under the multi-talented painter/architect/sculptor/engineer/theorist Francesco di Giorgio Martini. He headed for Rome at the age of twenty, honed his skills in architecture in Bramante's studio and eventually talked his way into the plum commission of the early Cinquecento, the villa of the Sienese banker Agostino Chigi, now known as the Farnesina. Once it was built Chigi set Raphael and Sebastiano del Piombo to decorate it but Peruzzi took up the brush as well. His astrological ceiling has long delighted Warburgians; a decade later his Sala delle Prospettive became a landmark of perspectival painting. Not a sculptor himself he nevertheless designed a bronze portal for Siena Cathedral and the marble tomb of Pope Adrian VI. He did churches and chapels in Bologna and Carpi. He lost everything in the Sack of Rome 1527 and was robbed of the very clothes on his back on the road to Siena. For the next eight years he had a successful career as supervisor of fortifications, operaio of the cathedral, designer of palaces and even engineer on a river dam. From Siena, he continued to collaborate with Antonio da Sangallo the Younger on St. Peter's and returned to Rome in 1535 to continue their teamwork. In the last months of his life he designed the cleverest domestic structure of Renaissance Rome, Palazzo Massimi alle Colonne.

Peruzzi is not widely known in the Anglo-Saxon world. Vasari mixed praise with condescension. He saw that this was an artist of towering talent, a painter of frescoes almost at the level of Raphael, a genius at perspective and master of the perspectival stage set, the best of his day in architecture and in painted facades. In fact, Peruzzi was so talented that Vasari felt obliged to give him a Florentine ancestry. He worked for kings, popes and cardinals and was always courteous and gentlemanly yet, Vasari laments, he lacked the force of character to squeeze money out of stingy patrons. He died a poor man, the greatest sin an artist could commit in Vasari's book. "Dappocaggine," good-for-nothingness, is the epithet Vasari hurled after this champion of the liberty of the Sienese Republic.

Specialists, however, have long known of Peruzzi's importance. Over the literature monographs on the major buildings and fortifications, a catalogue of the paintings, three conference volumes - stands the towering figure of Christoph Frommel. Little of this material is in English, however, so on that score alone Huppert's fine synthesis would be welcome. She is scrupulous in citing the work of her German and Italian predecessors but is also innovative in fields like architectural projection and 
archeological method. She writes with crystalline clarity and is a close reader of architectural drawings. This handsome Yale production is now the book to have for English readers on a central figure of the Roman Renaissance.

Huppert begins with Peruzzi's ravenous appetite for the remains of antiquity, the subject of half of his 500 drawings. One sense a "just the facts" personality in many of the quick pen sketches but also, at times, an artist searching to clarify the obscurities of Vitruvius. Huppert makes an extended comparison with the drawings of that consummate Vitruvius bloodhound, Antonio da Sangallo the Younger. Unlike Sangallo, however, Peruzzi was convinced, as Benvenuto Cellini observed, that Vitruvius had failed to choose the most beautiful examples from antiquity. The drawings show an eye for un-canonical detail and an analytic mind that dissects structure under ornament. Peruzzi never finished his treatise but gave fine drawings to Sebastiano Serlio, who warmly acknowledged the older artist's courtesy and generosity in his first book of 1537.

Huppert's title promises to show how a painter could become an architect. She does this through perspective and the culture of the stage. Latin plays were performed in front of the Farnesina and Peruzzi went on to design stage sets in perspective. He produced one of the most brilliant architectural drawings of the Renaissance (Uffizi $2 \mathrm{~A}$ ). Done in what would today be called axionometric projection, it gives us the impression that the building is going up before our eyes as we fly over it. Similarly a great drawing for San Petronio in Bologna lets us fly in and around the dome and chapels that Peruzzi proposed to add to the old nave.

Peruzzi was the soul of courtesy and all the artists of Rome turned out for his funeral in 1536, the first in the Pantheon after Raphael. Aside from the Farnesina ("born not built" says Vasari) and Palazzo Massimo Peruzzi's DNA is more widely distributed in the genome of Renaissance art than most realize. When we admire Veronese's great banquets with their architectural settings, or the Teatro Olimpico with its perspectival streets, or the oval and triangular churches of Bernini and Borromini, we are admiring the inheritance of Peruzzi. At last there is an English book that does him justice.

JOSEPH CONNORS

Harvard University 